\begin{tabular}{|c|c|c|}
\hline Gazi & GAZi iKTISAT VE işLETME DERGISi & Giid \\
\hline $\begin{array}{l}\text { KADEMIK } \\
\text { YINCILIK }\end{array}$ & GAZI JOURNAL OF ECONOMICS \& BUSINESS & GJEB \\
\hline
\end{tabular}

\title{
An operational performance assessment of Turkish airline companies based on return on invested capital tree model ${ }^{*}$
}

\author{
Nada Sarsour ${ }^{\text {a*** }}$, Eyad Aldalou ${ }^{\mathrm{b}}$ \\ ${ }^{a}$ Instructor, University of The People, Faculty of Business Administration, USA. Email: nadasarsour@ gmail.com \\ ORCID ID: https://orcid.org/0000-0002-0479-8780 \\ ${ }^{b}$ Instructor, University of The People, Faculty of Business Administration, USA. Email: eyad.e.a.a@gmail.com \\ ORCID ID: https://orcid.org/0000-0002-5960-3207
}

\section{ARTICLE INFO \\ Received: 19.07.2020 Accepted: 03.05.2021 Available online: 19.06 .2021 Article Type: Research paper}

\section{Keywords:}

Return on invested capital tree,

Financial performance, Operational performance, Air transportation.

\begin{abstract}
Studies in the air transportation industry generally consider either financial performance or operational performance regardless of the inevitable correlation between them. Sustaining a higher return on investment is achieved through higher efficiency and effective use of available resources. Thus, the investigation of operational factors as components of ROIC can help assessing the strengths and weaknesses of operations of a company. In this study, ROIC tree model has been identified. Within the model, operational performance factors of capacity utilization, passenger yield, labor cost, labor efficiency and fuel cost are considered and their effect on the profitability of a company is revealed. The assessment of the air transportation industry shows that improvement in capacity utilization and passenger yield can dramatically boost ROIC. However, policy improvements in labor cost, labor efficiency, and fuel cost are exceedingly achievable. This study presents a convenient and effective model for the airlines companies and offers handy directions for improving operational and financial performance. The suggested model enables the linkage of efficiency factors as profitability drivers and helps assessing sources of competitive advantage.
\end{abstract}

\section{Yatırım getirisi ağaç modeli kullanılarak Türk havayolu şirketlerinin operasyonel performansının değerlendirilmesi}

\begin{tabular}{|c|c|}
\hline MAKALE BİLGISİ & ÖZ \\
\hline $\begin{array}{l}\text { Geliş Tarihi: } 19.07 .2020 \\
\text { Kabul Tarihi: } 03.05 .2021 \\
\text { Cevrimiçi Kullanım } \\
\text { Tarihi: } 19.06 .2021 \\
\text { Makale Türü: Araştırma } \\
\text { makalesi }\end{array}$ & $\begin{array}{l}\text { Genelde, hava taşımacılık sektöründeki çalışmalar finansal ve } \\
\text { operasyonel performansı, arasındaki bağa bakmaksızın, ayrı ayrı } \\
\text { değerlendirmektedir. Sürdürülebilir yüksek yatırım getirisi, var olan } \\
\text { kaynakların etkin ve verimli bir şekilde kullanılmasıyla sağlanmaktadır. } \\
\text { Bu amaçla, operasyonel faktörlerin, yatırım getirisinin bilişenleri olarak }\end{array}$ \\
\hline
\end{tabular}

\footnotetext{
* This manuscript is the full text of the paper presented at the International Symposium on Business, Economics \& Education- Ankara, Turkey, held on April 4-5, 2020.

** Corresponding Author

Doi: https://doi.org/10.30855/gjeb.2021.7.2.001
} 
ele alınması şirketlerin operasyon faaliyetlerinin güçlü ve zayıf yanlarını ortaya çıkarmaktadır. Bu çalışmada, yatırım getirisi ağaç modeli geliştirmek amaçlanmıştır. Modelde, kapasite kullanımı, yolcu verimi, işgücü maliyeti, işgücü verimliliği ve yakıt maliyeti olarak operasyon faktörleri ele alınmış olup şirketin karlılığıyla ilişkisi

\section{Anahtar Kelimeler:}

Yatırım getirisi, Finansal performans, Operasyonel performans, Hava taşımacılı̆̆ şekillenmiştir. Çalışmada yapılan uygulama sonuçlarına göre, kapasite kullanımı ve yolcu verimindeki iyileşmeler yatırım getirisini önemli ölçüde arttırmaktadır. Yalnız, işgücü maliyeti, işgücü verimliliği ve yakıt maliyetindeki politika iyileştirmeleri fazlasıyla gerçekleştirilebilmektedir. Bu çalışma, hava taşımacılık şirketleri için operasyonel ve finansal performansı iyileştirmek için kullanışlı ve etkili bir model sunmaktadır. Önerilen model, verimlilik faktörlerinin karlılığı olumlu etkileyen bir faktör olarak bağlanmasını sağlamaktadır ve rekabet avantajı kaynaklarının değerlendirilmesine yardımcı olmaktadir.

\section{Introduction}

The remarkable growth of air transportation industry of Turkey is considered one of the main wheels driving the economic growth in the past decade. In which air transportation businesses' services assigned in the first place in the export services list (CAPA, 2018). The globalization and the sharp competition among the airline companies directed them toward improving productivity and controlling cost in order to improve their operational performance. Higher productivity attainment supports the competition strategy of a company with higher competitive advantage. Benefiting from the geographical location of Turkey, the Turkish air transportation industry derives its importance of playing leading role in Turkish economic. The recent success achieved by the Turkish air transportation industry not only reflects the advantage of its geographical location but also the wellorganized operating and financial performance of the companies, which highlights on the intensive competition among them to provide challengeable services.

The Turkish aviation network destination currently reaches the most of countries around the world, as in 2018, 171 agreements have been assigned with 171 countries. Turkish air transportation industry consists of eleven civil airline companies, only two of them are listed at Istanbul Stock Exchange which are; Turkish airlines (THY) and Pegasus airlines (PGS). According to annual report of Directorate General of Civil Aviation (DGCA) (2018) the Turkish aviation income is about 65 million Turkish Lira and about 200 thousand employees are working in aviation market. In addition, the annual average passenger growth rate since 2003 reached 13.3 percent. The total seat capacity of the market is 97,351 seats while the total cargo capacity is 2.19 million $\mathrm{kg}$. The THY's domestic and international market shares are 27.1 percent and 41.6 percent respectively, while PGS's domestic and international market shares are 28.3 percent and 9.8 percent respectively (Zuvin and Sozer, 2017).

Due to the importance of the air transportation sector, its assessment has been considered by many researchers employing different methods which include: MCDM methods (Feng and Wang 2000; Berrittella et al., 2009; Perçin, 2018), statistical methods such as panel data analysis and data envelopment analysis (Choi 2017; Kiraci and Yaşar, 2020) and financial ratios (Teker et al., 2016; Dayi and Ulusoy, 2018). Despite the importance of information impeded in the operational performance measures, less research is directed toward operational performance than financial performance assessment. Moreover, there was no evidence that operational performance measures provide information distinct from financial measures other than earnings and book value (Liedtka, 2002). Many other researches highlighted the importance of both operational and financial performance evaluation (Schefczyk, 1993; Tsikriktsis, 2007; Gyanwali and Walsh, 2020) for a comprehensive assessment.

Mostly, researchers considered the evaluation of operational and financial performance as two separated factors, and examined the mutual effects of these factors. In this study the main operational factors are examined as a Return on Invested Capital (ROIC) breakdown. Following (lee, 2019), the 
most important operational factors of airlines such as capacity utilization, passenger yield, labor cost, labor efficiency and fuel cost are to be measured by ROIC tree model. The proposed ROIC tree is used to assess the two airlines companies in Istanbul Stock Exchange, that is, Turkish airlines and Pegasus. Additionally, sources of low performance are clarified, and suggestions for improvement are proposed for a proper sustainable development tool.

\section{Literature review}

Air transportation industry has been examined in previous studies from different perspectives including service quality (Chen and Liu, 2017; Perçin, 2018; Deveci et al., 2018; Farooq et al., 2018; Gayle and Yimga, 2018; Sweis et al., 2019) performance efficiency, cost and productivity (Berrittella et al., 2009; Ajayi et al., 2010; Miranda et al., 2015; Wang et al., 2017; Choi 2017 Heshmati et al., 2018) social responsibility (Wang et al., 2015) operational and organizational performance (Schefczyk, 1993; Sweis et al., 2019; Kiraci and Yaşar, 2020; Gyanwali and Walsh, 2020) and financial performance (Feng and Wang, 2000; Baker et al., 2005; Teker et al., 2016; Hazarika and Boukareva, 2016; Mhlanga, 2017; Chen et al., 2017; Dayi and Ulusoy, 2018; Trisakti, 2018; Perçin and Aldalou, 2018; Kirac1, 2019). While, fewer studies have looked for both the financial and operational performance (Tsikriktsis, 2007; Lee, 2019).

Airlines companies relay not only on purchases but also on lease of aircraft and encounter different accounting and taxation rules, though, financial based performance assessment is difficult. Schefczyk (1993), suggested the inclusion of nonfinancial data into a data envelopment analysis model. The results of his analysis indicated that improved operational performance is a key driver of profitability, and factors such as passenger load factor, efficient resource acquisition are important for higher performance outcome.

To address whether financial and nonfinancial performance measures of the airline industry supply different information, Liedtka (2002) employed exploratory and confirmatory factor analysis. The results offered evidence that nonfinancial performance measures provide information not captured by financial measures. Such nonfinancial measures include labor efficiency, material efficiency and others.

In this study, the interrelation and overlap of data between financial and nonfinancial measures is driven. Ajayi et al., (2010) proposed measures for evaluating the operational efficiency and investigated the effect of operational efficiency over financial efficiency of U.S. airlines, considering different efficiency levels such as overall efficiency and scale efficiency, and concluded that mostly small companies have higher efficiency levels than large companies.

More recently, Wang et al., (2017) analyzed the efficiency of managing the light resources in order to handle challenges in the global industry benefiting from ROIC, Weighting Average Calculating Cost (WACC) and risk-free rate of return. Integrating the degree of assets lightness into regression analysis provides that a positive relationship excised between degree of assets lightness and dynamic efficiency. Gyanwali and Walsh (2020) considered the factors influencing performance of Nepal Airlines Corporation, and showed that the key performance factors include: motivated employee, collective leadership, entrepreneurial marketing and environmental support. They claimed thus such factors would succeed business in turbulent market.

\section{Proposed methodology}

In this study, the Return on Invested Capital (ROIC) tree model is used to evaluate the operational performance of airline companies as breakdown of ROIC. ROIC tree is a new approach that analyses the operational performance of a company as profitability drivers. It emphases on the main operational factors of an industry that contributes to the competitive advantage as well as the profitability (Damodaran, 2007).

The ROIC is a profitability measure that evaluate the rate of return a company can achieve on each dollar of invested capital. ROIC can be calculated as:

$$
\text { ROIC }=\frac{\text { Return }(\text { operating income after tax })}{\text { Invested Capital }}
$$


Return is calculated as operating income after tax, that is, before the deduction of interest expenses. As return is calculated on all capital thus all earnings to stockholders and lenders are included. In this regard, ROIC is considered a powerful profitability assessment measure where it indicates the ability of an entity to generate benefit to all stakeholders.

From Eq. 1,

$$
\begin{aligned}
& \text { ROIC }=\left(\frac{\text { Revenue-Cost }}{\text { Revenue }}\right) *\left(\frac{\text { Revenue }}{\text { Invested Capital }}\right) \\
& \text { ROIC }=\left(1-\frac{\text { operating Cost }- \text { other expenses \& taxes }}{\text { Revenue }}\right) *\left(\frac{\text { Revenue }}{\text { Invested Capital }}\right)
\end{aligned}
$$

Airline company's revenue represents all the proceeding from services provided to customer and passengers. Revenues can be expressed as in Eq. 4.

$$
\text { Revenue }=\text { Load Factor } * \text { Passenger Yield } * \text { Avaialble Seat per Kilometer }
$$

Where,

Load Factor (LF), is a capacity measure shows the usage of passenger capacity of an airline company,

Passenger Yield (PY), the average fare paid per kilometer, per passenger. It is the result of dividing revenue by revenue passenger kilometers (RPK). RPK shows the number of kilometers traveled by paying passengers,

Available Seat per Kilometer (ASK), is a capacity measure shows the total available passenger capacity of an airline company in kilometers.

The total passenger revenues of an airline company can be calculated by total available passenger capacity multiply by the capacity usage percentage and revenue per unit of kilometer per passenger.

Financial operating performance of airline companies are mostly evaluated considering the same cost factors which categorized into two main categories; direct costs includes all costs associated with fuel cost and flight crew as these costs incurred directly while operating aircrafts as well as other operating and administration expenses and taxes. Direct labor costs can be considered as in Eq. 5 .

$$
\text { Labor costs }=\frac{\text { Labor Costs }}{\text { Number of Employees }} * \frac{\text { Number of Employees }}{A S K} * A S K
$$

Where, $\frac{\text { Labor Costs }}{\text { Number of Employees }}$ is a labor cost efficiency measure shows the burden associated with the use of labor, $\frac{\text { Number of Employees }}{A S K}$ is a labor productivity measure shows how much labor is used to produce a unit of ASK.

In the same manner, direct fuel costs can be considered as in Eq. 6.

$$
\text { Fuel costs }=\frac{\text { Fuel Cost }}{\text { Amount of Fuel (gallon) }} * \frac{\text { Amount of Fuel }}{A S K} * A S K
$$

Where, $\frac{\text { Fuel cost }}{\text { Amount of Fuel (gallon) }}$ is a Fuel cost efficiency measure shows the price bargain ability and the effectiveness of fuel acquirement policy of the company, $\frac{A m o u n t ~ o f ~ F u e l}{A S K}$ is a fuel productivity measure shows how much fuel (gallon) is used per unit of ASK.

Using Eq. 4, 5 and 6. The rate of return for airlines companies can be expressed as in Eq. 7.

$$
\frac{\text { Return }}{\text { Revenue }}=1-
$$

$\left(\frac{(\text { Labor Cost per employee } * \text { labor effciency } * A S K)+(\text { fuel cost per unit } * \text { fuel ef ficiency } * A S K)}{(\text { Load Factor } * \text { Passenger Yield } * \text { Avaialble Seat per Kilometer })}\right)$

$$
-\left(\frac{\text { Selling General \& administrative and Tax expenses }}{(\text { Load Factor } * \text { Passenger Yield } * \text { Avaialble Seat per Kilometer })}\right)
$$


Where, $\frac{S G \& A+\text { Taxes }}{\text { Revenues }}$, is an operational efficiency measure shows the amount of selling, general \& administrative expenses and taxes used to produce a unit of revenue.

Invested capital represents all the assets invested in the company which consists of working capital and fixed assets. Working capital amount of investment used to run daily operations. It can be calculated as Eq. 8.

$$
\text { Working Capital }=\text { Accounts receivables }+ \text { Inventory }- \text { Accounts Payables }
$$

On the other hand, fixed assets of airline companies consist of capital invested in planes (aircraft capital), aircraft related assets and other long term assets. Based on the extracted operational factors the formula of ROIC tree model as Eq. 9.

$$
R O I C=(1-
$$

$\left(\frac{(\text { Labor Cost per Employee } * \text { Labor Effciency } * \text { ASK })+(\text { Fuel Cost per Unit } * \text { Fuel Efficiency } * \text { ASK })}{(\text { Load Factor } * \text { Passenger Yield } * \text { Avaialble Seat per Kilometer })}\right)-$

$\left.\left(\frac{\text { Selling General \& administrative and Tax expenses }}{(\text { Load Factor } * \text { Passenger Yield } * \text { Avaialble Seat per Kilometer })}\right)\right) *$

$\left(\frac{\text { Load Factor } * \text { Passenger Yield } * \text { Avaialble Seat per Kilometer }}{\text { Working Capital+Aircraft Capital }+ \text { Aircraft Related Capital+other Long Term Asssets }}\right)$

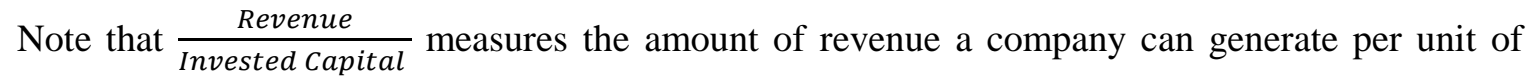
invested capital. Figure 1 shows the ROIC tree model proposed in this study.

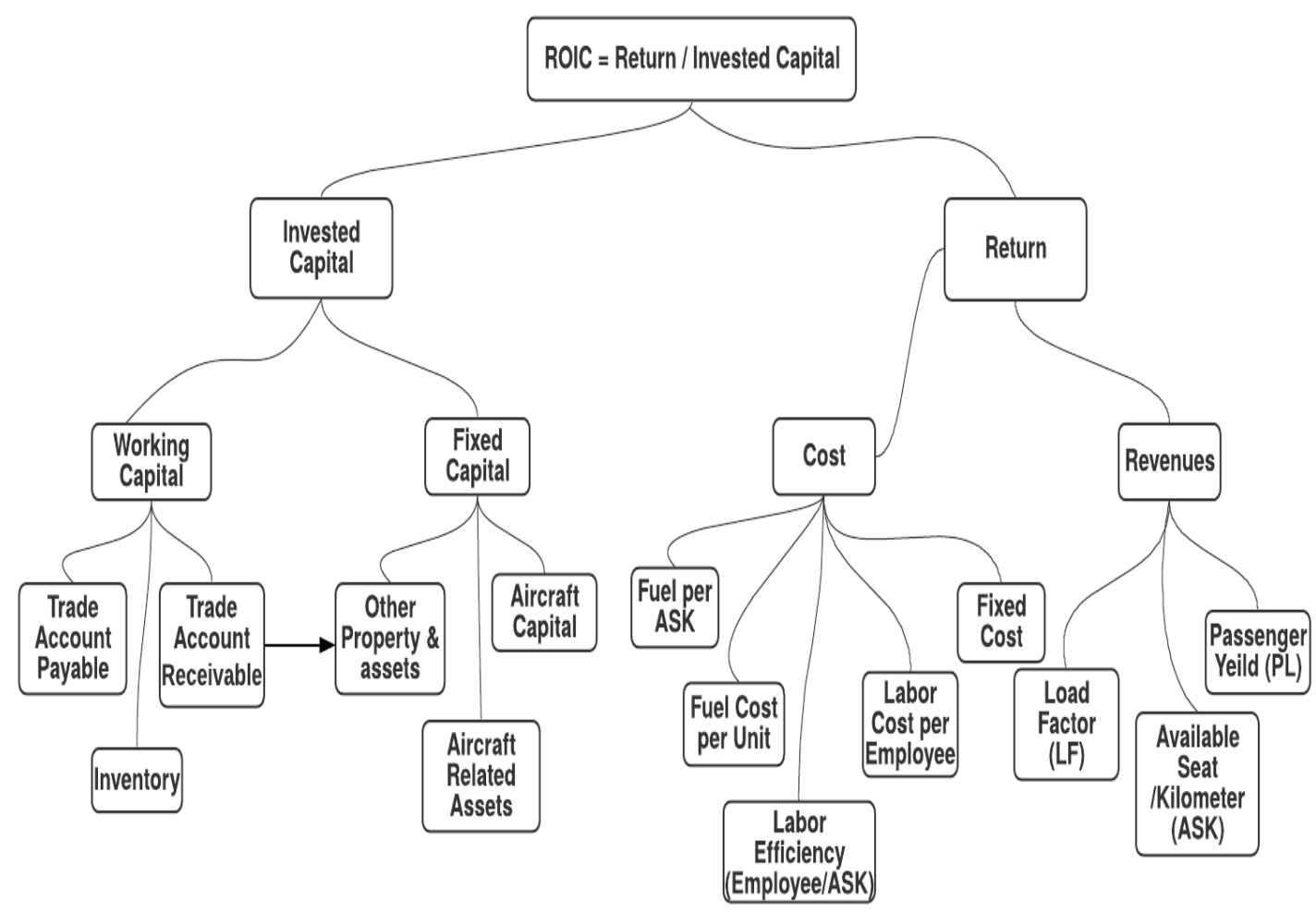

Figure 1. ROIC Tree Model

\section{Application and discussion}

For the purpose of assessing the effects of operational performance over financial performance, the ROIC tree and its calculations are applied to Turkish Airlines and Pegasus Airlines for 2018. Data is contracted from the annual reports and official websites of both companies. ROIC is calculated and equal to $7.10 \%$ for Turkish Airlines and $8.67 \%$ for Pegasus Airlines. Before assessing the effects of 
operational performance, a comparison between ROIC, return on assets ROA and return on equity ROE is introduced, as shown in Table 1:

Table 1

A Comparison Between ROIC, ROA and ROE

\begin{tabular}{lccc}
\hline Airlines Companies & ROIC & ROA & ROE \\
\hline Turkish Airlines (THY) & $7.10 \%$ & $3.71 \%$ & $12.93 \%$ \\
Pegasus Airlines (PGS) & $8.67 \%$ & $3.68 \%$ & $13.51 \%$ \\
\hline
\end{tabular}

Table 1 shows that Turkish Airlines generates a higher ROA than Pegasus Airlines. However, based on ROIC and ROE it seems that Pegasus Airlines can provide more value to its investors and owners. Data calculated for both companies are shown in Table 2. The amount of return generated out of revenue for THY is a little higher than for PGS. However, the amount of revenue produced out of invested capital is considerably higher for PGS which justifies the higher ROIC ratio.

As can be noticed from Table 2, THY has a higher passenger yield (PY=0.421) for 2018, while, PGS has higher capacity utilization $(\mathrm{LF}=0.855)$, however in most efficiency measures considered earlier, PGS showed a better performance as; less costs are paid per employee, less labor forces are used per ASK, lower amount of fuel is used per ASK and lower amount of operating costs are paid to produce a unit of revenue. All of which minimized the effect of a very higher PY rate of THY over PGS. Plane capital per plane for PGS is considerably lower than THY. In general, despite the higher ability of THY to gain a higher yield per passenger, the higher efficiency and productivity components of ROIC for PGS lead to higher benefit generated to stakeholders.

Table 2

Results of ROIC Tree for Both Companies

\begin{tabular}{lcc}
\hline Factor & THY & PGS \\
\hline Revenues TL & 62853000000 & 8296736033 \\
PY & 0.421 & 0.273 \\
LF & 0.819 & 0.855 \\
RPK & 149169213042 & 30389265000 \\
ASK & 182030828951 & 35543000000 \\
Labor Costs TL & 6637000000 & 788828099 \\
Number of Employees & 30719 & 5621 \\
Cost per Employee TL & 216055 & 140336 \\
Labor Efficiency & 0.036 & 0.022 \\
Fuel Cost TL & 18478000000 & 2729667414 \\
Fuel Amount & 5277311 & 780101 \\
Fuel Unit Cost TL & 3501 & 3499 \\
Fuel Efficiency & 0.102 & 0.077 \\
Selling G.\&A. Efficiency & 0.506 & 0.482 \\
Working Capital TL & -1373000000 & -289829778 \\
Plane Capital TL & 61321000000 & 7209935976 \\
Number of Planes & 332 & 82 \\
Invested Capital per Plane TL & 184701807 & 87926048 \\
Total Fixed Capital TL & 85370000000 & 9252807145 \\
Invested Capital TL & 83997000000 & 8962977367 \\
Return/Revenue & 0.0949 & 0.0937 \\
Revenue/Invested Capital & 0.748 & 0.926 \\
\hline
\end{tabular}


In order to assess the effect of operational performance over financial performance, five operational performance factors are considered. 5\% improvement is considered on each factor separately.

Table 3

The Effects of Improving Operational Factors on ROIC

\begin{tabular}{lcc}
\hline \multicolumn{1}{c}{ Operational Factors } & THY & PGS \\
\hline The Calculated ROIC & $7.10 \%$ & $8.67 \%$ \\
\hline $5 \% \uparrow$ Capacity Utilization (Load Factor) & $10.84 \%$ & $13.30 \%$ \\
\hline $5 \% \uparrow$ Passenger Yield & $10.84 \%$ & $13.30 \%$ \\
\hline $5 \% \downarrow$ Labor Cost & $7.48 \%$ & $9.09 \%$ \\
\hline $5 \% \uparrow$ Labor Efficiency & $7.48 \%$ & $9.09 \%$ \\
\hline $5 \% \downarrow$ Fuel Cost & $8.15 \%$ & $10.12 \%$ \\
\hline
\end{tabular}

Based on Table 3, the 5\% improvement in capacity utilization or passenger yield result about more than 50\% improvement in ROIC for both companies. While, 5\% improvement in ROIC resulted from improving in labor cost or labor efficiency, and 5\% improvement in fuel cost results an approximately $15 \%$ improvement in ROIC. Not to forget that most of capacity usage improvement methods come with lower return and higher prices lead to lower capacity utilization. Thus, the company needs to be very careful seeking capacity and yield policies for return improvement. Of course, labor training, and fuel hedging might mean more cost to the company. However, the higher labor efficiency may lower the labor usage to cover for these costs and achieve a higher efficiency. In the same regard, the cost of a fuel option or agreement might be much lower than the increase in prices. For which, focus of such matter may represent a key to new efficiency levels.

Additionally, two factors are selected to connect efficiency factors of ROIC tree and productivity factors, that is; labor productivity and plane capital productivity. Both productivity measures are calculated for both companies and shown in Table 4.

Table 4

Labor and Plane Capital Productivity

\begin{tabular}{lcc}
\hline \multicolumn{1}{c}{ Operational Factors } & THY & PGS \\
\hline Labor Productivity & 9.470 & 10.518 \\
Plane Capital Productivity & 1.025 & 1.151 \\
\hline
\end{tabular}

As can be noticed from Table 4. PGS has higher labor and plane capital productivity than THY. That is; it can produce more revenues per dollar invested in labor. These results are the same as results obtained from ROIC tree.

\section{Conclusion}

The recent success achieved by the Turkish air transportation industry not only reflects the advantage of its geographical location but also the well-organized operating and financial performance of the companies, which highlights on the intensive competition among them to provide attractive services. In this regard, the assessment of airline companies needs to consider both operational and financial performance factors. This study develops a ROIC tree model to link the operational factors of an airline company such as labor and fuel efficiency to the ROIC.

Factors such as; capacity usage, labor cost per employee, labor efficiency, fuel cost per unit, fuel efficiency, operational efficiency, profit generation, assets usage and other factors can be tracked by the breakdown of ROIC ratio. Such effort helps addressing the strengths and weaknesses of a company and clarifies its sources. It also provides a proper development tool that determine the area of development and how to measure the expected assessment results. 
The application of the proposed assessment showed a very higher PY for THY. Yet, higher LF, less costs are paid per employee, less labor forces are used per ASK, lower amount of fuel is used per ASK and lower amount of operating costs are paid to produce a unit of revenue for PGS resulted in higher rate of ROIC for 2018.

The operational components of ROIC tree model can provide the information that are obtained by normal efficiency measure. That is the labor efficiency factor shows the amount of labor used per ASK provide a parallel information with labor productivity measure.

This study presents a convenient and effective model for the airlines companies that offers handy directions for improving operational and financial performance. Future researches may consider the application of ROIC tree model to other sectors.

\section{References}

Ajayi, R. A., Mehdian, S., and Guzhva, V. S. (2010). Operational efficiency in the US airline industry: An empirical investigation of post-deregulation era. Review of Economic and Business Studies, 3(2), 51-63.

Baker, C. R., Ding, Y., and Stolowy, H. (2005). Using "statement of intermediate balances" as tool for international financial statement analysis in airline industry. Advances in International Accounting, 18, 169198.

Berrittella, M., La Franca, L., and Zito, P. (2009). An analytic hierarchy process for ranking operating costs of low cost and full service airlines. Journal of Air Transport Management, 15(5), 249-255.

CAPA (2018). Turkish Airlines SWOT: More growth for the Istanbul super connector Centre for Aviation. CAPA. https://centreforaviation.com/analysis/airline-leader/turkish-airlines-swot-more-growth-for-theistanbul-superconnector-449802 (accessed: January 2020)

Chen, C. M., and Liu, H. M. (2017). Exploring the impact of airlines service quality on customer loyalty: Evidence from Taiwan. International Journal of Business and Management, 12(5), 36-50.

Chen, S. J., Chen, M. H., and Wei, H. L. (2017). Financial performance of Chinese airlines: Does state ownership matter? Journal of Hospitality and Tourism Management, 33, 1-10.

Choi, K. (2017). Multi-period efficiency and productivity changes in US domestic airlines. Journal of Air Transport Management, 59, 18-25.

Damodaran, A. (2007). Return on capital (ROC), return on invested capital (ROIC) and return on equity (ROE): Measurement and implications. SSRN. https://papers.ssrn.com/sol3/papers.cfm?abstract_id=1105499

Dayi, F., and Ulusoy, T. (2018). Evaluating financial performance with minimum spanning tree approach: an application in airlines companies. Electronic Turkish Studies, 13(30).

Deveci, M., Özcan, E., John, R., and Öner, S. C. (2018). Interval type-2 hesitant fuzzy set method for improving the service quality of domestic airlines in Turkey. Journal of Air Transport Management, 69, 83-98.

DHMI Annual Report, (2018). Annual statistics of Turkish airports. http://www.dhmi. gov.tr/dosyalar/annualreport/ (Accessed 17 Dec. 2019).

DHMI. (2017). General directorate of state airports authority Turkey. https://www.icao.int/MID/Documents/2017/Aviation\%20Data\%20and\%20Analysis\%20Seminar/PPT10\%20 -\%20Turkish\%20DHMI.pdf

Farooq, M. S., Salam, M., Fayolle, A., Jaafar, N., and Ayupp, K. (2018). Impact of service quality on customer satisfaction in Malaysia airlines: A PLS-SEM approach. Journal of Air Transport Management, 67, 169-180.

Feng, C. M., and Wang, R. T. (2000). Performance evaluation for airlines including the consideration of financial ratios. Journal of Air Transport Management, 6(3), 133-142.

Gayle, P. G., and Yimga, J. O. (2018). How much do consumers really value air travel on-time performance, and to what extent are airlines motivated to improve their on-time performance? Economics of transportation, 14, $31-41$.

Gyanwali, S., and Walsh, J. C. (2020). Influencing factors of organizational performance in Nepal airlines corporation. International Business Research, 13(1), 268-283. 
Hazarika, I., and Boukareva, B. (2016). Performance analysis of major airline companies in UAE with reference to profitability, liquidity, efficiency, employee strength and productivity. Eurasian Journal of Business and Management, 4(4), 71-80.

Heshmati, A., Kumbhakar, S. C., and Kim, J. (2018). Persistent and transient efficiency of international airlines. European Journal of Transport and Infrastructure Research, 18(2).

Kirac1, K. (2019). Financial Risk and Financial Performance: The impact of the global financial crisis on airlines. Researches in Economics Econometrics \& Finance, 257.

Kiraci, K., and Yaşar, M. (2020). The determinants of airline operational performance: an empirical study on major world airlines. Sosyoekonomi, 28(43), 107-117.

Lee, J. (2019). Effects of operational performance on financial performance. Management Science Letters, 9(1), 25-32.

Liedtka, S. L. (2002). The information content of nonfinancial performance measures in the airline industry. Journal of Business Finance \& Accounting, 29(7-8), 1105-1121.

Mhlanga, O. (2017). Sources of financial turbulence for private airlines in South Africa: An empirical study. African Journal of Hospitality, Tourism and Leisure, 6(2), 1-13.

Miranda, M., Baltazar, M. E., and Silva, J. (2016). Airlines performance and efficiency evaluation using a MCDA methodology. The case for low cost carrier vs legacy carriers. Open Engineering, 6(1).

Pegasus Official website: http://www.pegasusinvestorrelations.com/en and: https://www.flypgs.com/ (accessed November-December, 2019).

Perçin, S. (2018). Evaluating airline service quality using a combined fuzzy decision-making approach. Journal of Air Transport Management, 68, 48-60.

Perçin, S., and Aldalou, E. (2018). Financial performance evaluation of Turkish airline companies using integrated fuzzy AHP fuzzy TOPSIS model. Uluslararası İktisadi ve İdari Incelemeler Dergisi, 583-598.

Schefczyk, M. (1993). Operational performance of airlines: an extension of traditional measurement paradigms. Strategic Management Journal, 14(4), 301-317.

Sweis, R. J., Elhawa, N. A., and Sweis, N. J. (2019). Total quality management practices and their impact on performance: case study of Royal Jordanian Airlines. International Journal of Business Excellence, 17(2), 245-263.

Teker, S., Teker, D., and Güner, A. (2016). Financial performance of top 20 airlines. Procedia-Social and behavioral sciences, 235, 603-610.

Trisakti, U. (2018). Financial ratio and performance airlines industry with DEA and TOPSIS model. International Journal of Pure and Applied Mathematics, 119(10), 367-374.

Tsikriktsis, N. (2007). The effect of operational performance and focus on profitability: A longitudinal study of the US airline industry. Manufacturing \& Service Operations Management, 9(4), 506-517.

Turkish Airlines official website: https://www.turkishairlines.com/, (accessed November-December, 2019).

Wang, Q., Wu, C., and Sun, Y. (2015). Evaluating corporate social responsibility of airlines using entropy weight and grey relation analysis. Journal of Air Transport Management, 42, 55-62.

Wang, W. K., Lin, F., Ting, I. W. K., Kweh, Q. L., Lu, W. M., and Chiu, T. Y. (2017). Does asset-light strategy contribute to the dynamic efficiency of global airlines? Journal of Air Transport Management, 62, 99-108.

Zuvin, S. and Sozer, B. (2017). The aviation sector, including airport capacities, airline acquisitions and alliances and the regulation of UAVs, in 15 jurisdictions. The Strategic View - Aviation, Turkey (https://www.strategicview.co.uk/strategic-view/aviation-law/the-strategic-view-aviation-2017/turkey) 